\title{
Japan topples tradition with move to foreign reviewers
}

Tokyo. In an unprecedented move likely to send shock waves through Japan's university research system, Tokyo University, the leading national university, has asked several eminent Western and Japanese scientists to carry out an external evaluation of its physics department, one of its strongest research-orientated programmes. The review,

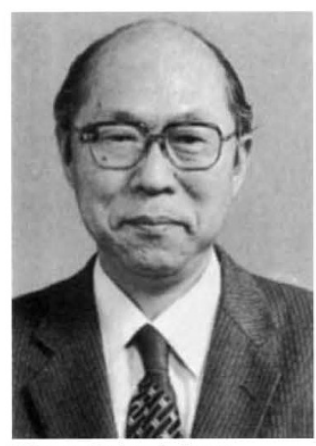

which will take place next month, will put pressure on university research departments throughout Japan to carry out similar reviews, because Japan's universities are now entering an era of increased competition due to a rapid demographic decline in

the student population that will continue over at least the next 20 years.

Most of Japan's universities are only just beginning to grapple with the concept of 'self-evaluation' thrust upon them last year by the University Council, an advisory body to the Ministry of Education, Science and Culture (Monbusho). But even selfevaluation is only an internal affair. Tokyo University's move takes evaluation two leaps further. Not only is the review external, like the regular reviews already carried out the Institute of Physical and Chemical Research (RIKEN, see Nature 359, 578; 1992) it will be the first external review of any research organization in Japan to involve non-Japanese scientists.

Under the self-evaluation system all of Japan's universities must produce annual reports showing their strengths and weaknesses. Next week, Tokyo University will release its report, or 'white paper' (hakusho) as it is officially called. This volume of more than 600 pages covers many problems, such as reform of the graduate school and the general education faculty, and points out deficiencies in personnel and facilities. But, as one of the deans of Tokyo University admits, the hakusho is largely "propaganda" and contains little "true evaluation".

The much more revolutionary external review of the physics department in January is the brainchild of Tokyo University's maverick president, Akito Arima, and the dean of the university's faculty of science, Ikuo Kushiro. At Arima's urging, Kushiro proposed the review to Arima, who came back with an "unexpectedly large budget", says Kushiro. That will enable the university to bring in several eminent scientists from overseas, including Jean Audouze, science adviser to the French government, David Pines of the University of Illinois in the United States, Sydney Brenner, of the University of Cambridge in Britain, and Yoichiro Nambu of Chicago University.

There will also be several reviewers from Japan, among them Nobel prizewinner Leo Esaki, president of Tsukuba University, Minoru Oda, president of RIKEN, and Junjiro Kanamori, president of Osaka University.

Arima's choice of the physics department is not accidental - he used to work there and he knows that it is one of the best departments in the university. But, like all departments in Japanese national universities, the physics department is literally falling apart and suffers from a chronic shortage of staff, in particular technicians, due to a government policy that cuts the number of government employees (including staff of national universities) each year.

Arima, who has rushed the evaluation process forward before his retirement as president at the end of March, clearly hopes to use the external review as a shining example of what Tokyo University has achieved in the face of adversity. And he and Monbusho will undoubtedly employ the review to constrain the Ministry of Finance into giving the university more money.

Kimito Kubo, deputy director of the university division of Monbusho's Higher Education Bureau, says that the University Council had hoped to introduce such a process of external review, but had to settle for "self-evaluation" in the face of resistance from some universities. But such a review process is "absolutely necessary", he says, and it will have a "big effect" on Japan's other 97 national universities.

Tokyo University's head-start may even turn out to be canny strategy for more funding. There is a new mechanism by which Monbusho and universities can reward departments that come out favourably under such reviews. To improve graduate level education, the ministry this year introduced a new fund, the Special Fund for Promotion of Research in Higher Education, of $¥ 4,000$ million ( $\$ 32$ million). With the new fund, special grants of $¥ 10$ - 100 million, over and above normal university funding, can be given to university departments or divisions carrying out exceptionally good research at the graduate level. This year the money was distributed fairly evenly, but next year Monbusho and the universities will probably begin to pick and choose between departments and research groups based on the evaluations now under way.

David Swinbanks

\section{RITE more right for foreigners than Japanese}

Kyoto. It seems Japan's young scientists are not yet ready to part with the tradition of lifetime employment. In an attempt to introduce Western employment practices to find the best talent and avoid lifetime commitments, the new, lavishly funded Research Institute of Innovative Technology for the Earth (RITE) this summer launched a recruitment drive offering high salaries - but nonpermanent positions -- for the first jobs at RITE's main research facility which will open next year in Kansai science city between Kyoto, Nara and Osaka. But, while RITE has been inundated with applications from overseas, very few Japanese have applied.

RITE was established two years ago and has a budget this year of more than $¥ 6$ billion (\$50 million). It arranges and funds joint research between government laboratories and industry to develop 'environment friendly' technology, such as biodegradable plastics and substitutes for chlorofluorocarbons.

With the opening of the new Kansai research facility next summer, RITE can begin its own in-house research. The new facility, destined to have a gleaming roof of solar cells that will provide about 10 per cent of the centre's electricity needs, is being built with donations of $¥ 4$ billion from industry on a vast 40,000 square metre plot of land provided free of charge by Kyoto prefectural government, and it will have all the latest high-technology equipment. But a spacious environment, lavish facilities and the prospect of high salaries is proving insufficient to attract bright young Japanese.

RITE advertised extensively in Japan for applicants for the first 5-10 positions in the research facility, which will eventually have about 50 research personnel. RITE also placed one advertisement in Nature (Nature 16 July 1992 , Classified 18). By the application deadline a few weeks ago, 63 people had applied. But, to the dismay of RITE, only 13 were Japanese; the remaining 50 were from 18 overseas countries, including the United States, France, the Netherlands, Russia, China, Sri Lanka, Hungary, Bangladesh, the Philippines, Pakistan, Iran, Bulgaria, Czechoslovakia and Mexico.

Japanese researchers appear to have been put off by the employment terms. RITE offers negotiable contracts of up to five years duration with salary dependent on qualifications. It is prepared to offer very generous salaries to the right people, but apparently Japanese shied away from applying because of the lack of guaranteed permanent employment, says T sutomu Yamaguchi, RITE's senior managing director. In Japan, nearly all research jobs in government and industry guarantee lifetime employment.

David Swinbanks 